\title{
Design, Synthesis and Biological Evaluation of New Potent and Highly Selective Ros1-Tyrosine Kinase Inhibitor
}

\author{
Byung Sun Park, ${ }^{\mathrm{c}}$ Ibrahim M. El-Deeb, ${ }^{\mathrm{b}}$ Kyung Ho Yoo, ${ }^{\mathrm{a}}$ Chang-Hyun Oh, ${ }^{\mathrm{a}}$ \\ Seung Joo Cho, ${ }^{\text {,e }}$ Dong Keun Han, ${ }^{a}$ Hye-Seung Lee, ${ }^{\mathrm{f}}$ Jae Yeol Lee, ${ }^{\mathrm{c}}$ and So Ha Lee ${ }^{\mathrm{a}, *}$ \\ ${ }^{\mathrm{a}}$ Life Sciences Research Division, Korea Institute of Science and Technology, P.O. Box 131, \\ Cheongryang, Seoul 130-650, Republic of Korea \\ ${ }^{b}$ Department of Biomolecular Science, University of Science and Technology, 113 Gwahangno, \\ Yuseong-gu, Daejeon 305-333, Korea \\ ${ }^{c}$ Research Institute for Basic Sciences and Department of Chemistry, College of Science, \\ Kyung Hee University, Seoul 130-701, Korea \\ ${ }^{d}$ Research Center for Resistant Cells, Chosun University, Gwangju 501-759, Republic of Korea \\ ${ }^{e}$ Department of Cellular and Molecular Medicine, College of Medicine, Chosun University, 375 Seosuk-dong, \\ Dong-gu Gwangju 501-759, Republic of Korea \\ ${ }^{f}$ Marine Natural Products Laboratory, Korea Ocean Research \& Development Institute, Ansan P.O.Box 29,
} Seoul 425-600, Korea

\begin{abstract}
Ros1 protein is a receptor tyrosine kinase that has been reported mainly in meningiomas and astrocytomas, and until now, there is no selective in hibitor for th is kinase. In th is study, we illu strate for the synthesis of a highly potent and selective inhibitor for Ros 1 kinase. The synthesized compound 1 was tested initially at a single dose concentration of $10 \mu \mathrm{M}$ over 45 different kinases. At this concentration, a $94 \%$ inhibition of the enzymatic activity of Ros 1 kinase was observed, while the inhibition in activity was below $30 \%$ in all of the other kinases. The pyrazole compound 1 was further tested in a 10 -dose $\mathrm{IC}_{50}$ mode and showed an $\mathrm{IC}_{50}$ value of $199 \mathrm{nM}$ for Ros1 kinase. Our compound 1 can be used as a promising lead for the development of new selective inhibitors for Ros1 kinase, and it may open the way for new selective therapeutics for astrocytomas.
\end{abstract}

Signal transduction is an essential biological process for normal cell growth and function. The transduction of many of $t$ hese $s$ ignals i $\mathrm{s} m$ ediated $t$ hrough gr owth factors $w$ hich tr ansmit their s ignals in to th e c ell b y a group of trans-membrane $\mathrm{p}$ roteins $\mathrm{w}$ ith in trinsic tyrosine kinase activity, named receptor tyrosine kinases (RTKs). ${ }^{1-4}$ Mutations a t RTKs e ncoding ge nes a re associated $\mathrm{w}$ ith $\mathrm{t}$ he $\mathrm{i}$ ncidence o $\mathrm{f} s$ everal $t$ ypes o $\mathrm{f}$ cancers. ${ }^{5-8}$ Ros 1 is a human ge ne that e ncodes for a trans-membrane $r$ eceptor tyrosine ki nase. ${ }^{9-11}$ It is located at the chromosome 6 region $6 \mathrm{q} 16 \rightarrow 6 \mathrm{q} 22 .{ }^{9}$ This region of $\mathrm{c}$ hromosome $6 \mathrm{i} \mathrm{s}$ i nvolved i $\mathrm{n}$ non -random chromosomal ar rangements $\mathrm{i} n \mathrm{~s}$ pecific $\mathrm{n}$ eoplasias including a cute 1 ymphoblastic 1 eukemias, malignant melanoma, and ovarian carcinoma. ${ }^{9}$ A microdeletion at $6 q 21$ of Ros1 results in the fusion of a golgi apparatus associated protein called F IG (Fused in G lioblastoma), to $t$ he ki nase dom ain of $t$ he pr otoncogene Ros1 producing a $\mathrm{c}$ himeric pr otein $\mathrm{W}$ ith a $\mathrm{c}$ onstitutive receptor tyrosine kinase activity. ${ }^{12,13}$

Keywords: Ros1; $\mathrm{T}$ yrosine k inase; Kinase in hibitor; Astrocytoma; Glioblastoma multiforme; Pyrazole; Selectivity; Cancer.

* Corresponding authors. Tel.: +82 2958 6834; fax: +82 29585189

E-mail addresses: LSH6211@kist.re.kr
This fused chimeric protein is a potent oncogene and its transforming potential lies in its ability to in teract with golgi apparatus. $^{12}$

The ectopic expression of Ros1 receptor protein has been reported mainly in meningiomas and astrocytomas (25\% of 1 ow gr ade a nd $30 \%$ of $\mathrm{m}$ alignant $\mathrm{gl}$ ioma tumors) suggesting a key role for Ros1 in these CNS malignancies. ${ }^{12,14}$ A survey of 45 different human tumor cell lines, made by Birchmeier et al., ${ }^{11}$ has showed that Ros1 was expressed in glioblastoma-derived cell lines at high levels, while not expressed at all or expressed minimally in the remaining cell lines. ${ }^{11}$

Glioblastoma multiforme is the $\mathrm{m}$ ost advanced astrocytic neoplasm, and is one of the most aggressive human cancers with a median survival of less than one year. $\mathrm{T}$ he $\mathrm{c}$ omplete $\mathrm{r}$ esection of $\mathrm{gl}$ ioblastoma $\mathrm{i} \mathrm{s}$ impossible be cause of the diffuse infiltration of tumor cells into normal parenchyma. In addition, these tumors are hi ghly $\mathrm{r}$ esistant $\mathrm{t}$ or adiation a nd $\mathrm{c}$ hemotherapy. Despite $d$ ecades o $\mathrm{ft}$ herapeutic $r$ esearch, ef fective chemotherapeutic treatment for high grade astrocytomas is not yet a vailable, and patient care ultimately focuses on palliative management. ${ }^{15-18}$

Herein, w e $r$ eport the di scovery of a pot ent a nd highly s elective Ros1 RTK in hibitor 1 (Figure 1). The 
synthetic an $\mathrm{d} s$ creening protocols for the i nhibitor are illustrated in d etails. T he ki nase i nhibitory a ctivity of the synthesized compound was tested over 45 different kinases, and it showed high selectivity for Ros1 kinase. According to o ur knowledge, th is is the first s elective Ros1 tyrosine kinase inhibitor.

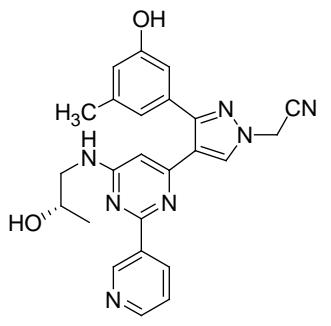

Figure 1. Structure of pyrazole compound 1

For the s ynthesis of the $t$ arget compound 1, it w as important a $\mathrm{t} f$ irst to pr epare the ke y e ster, methyl 3 methoxy-5-methylbenzoate (5) as illustrated in Scheme 1. The synthesis started with the preparation of the sodium s alt of e thyl 2 -hydroxy-4-oxopent-2-enoate (2) according to lite rature procedure, ${ }^{19}$ through $t$ he condensation of diethyl oxalate $w$ ith acetone in the presence of s odium e thoxide in a bsolute ethanol. The resulted s alt $\mathbf{2}$ was t hen c yclized i nto $\mathrm{C}$ laisen $\mathrm{f}$ uran derivative 3 by heating in $50 \%$ acetic acid followed by acidification with sulfuric acid. ${ }^{20}$ The resulted $\mathrm{C}$ laisen compound un derwent rearrangement and a romatization into 3 -hydroxy-5-methylbenzoic aci d (4) w ithin le ss than one hour by he ating with magnesium oxi de i $\mathrm{n}$ boiling $\mathrm{w}$ ater, $\mathrm{f}$ ollowed $\mathrm{b}$ y a cidification $\mathrm{w}$ ith hydrochloric aci d to precipitate the pr oduct. ${ }^{20}$ Methyl esterification a nd $O$-methylation o $\mathrm{f}$ th e $\mathrm{r}$ esulted phenolic acid 4 were a chieved in a s ingle s tep and in high yield (94\%) to give compound 5 through a little modification of the 1 iterature pr ocedure, ${ }^{21}$ where the acid 4 was $r$ efluxed $w$ ith e xcess pot assium $\mathrm{c}$ arbonate and $\mathrm{i}$ odomethane $\mathrm{i} n$ acet one $\mathrm{i} \mathrm{nt}$ he $\mathrm{p}$ resence of a catalytic amount of DMAP.

In Scheme 2, the benzoate ester 5 underwent a nucleophilic a ttack a $\mathrm{t} i$ ts carboxylic $\mathrm{c}$ arbon by $\mathrm{t}$ he activated methylene gr oup of 2,4 -dichloro-6-methylpyrimidine. The activation of this methyl group into an active methylene was achieved by dropwise addition of lithium b is(trimethylsilyl)amide (LHMDS) in d ry T HF at room temperature. The resulted tautomeric $\alpha, \beta$ unsaturated ke tone 6 was $\mathrm{t}$ hen $\mathrm{s}$ ubjected $\mathrm{t}$ o a nucleophilic substitution reaction with the amino group of (S)-(+)-1-aminopropan-2-ol by he ating at $80{ }^{\circ} \mathrm{C}$ i n dry THF for 3 hours. Two regioisomers were produced from this reaction, but the major isomer was $(S)-2-(6-(2-$ hydroxypropyl-amino)-2-chloropyrimidin-4-yl)-1-(3methoxy-5-methylphenyl)ethanone (7), wh ich wa s separated in a pure form using column chromatography. The structure of this isomer was confirmed by the 2D-
NOESY NM R s pectrum of the s ubsequent $\mathrm{c}$ ompound 10. The conversion of the resulted tautomeric product 7 to $t$ he $r$ equired $p$ yrazole $d$ erivative 8 was ach ieved through $\mathrm{t}$ wo su ccessive st eps. I $\mathrm{nt}$ he $\mathrm{f}$ irst st ep, compound 7 was h eated w ith ex cess $N, N$ dimethylformamide dimethylacetal for 20 hours, and the resulted pr oduct $\mathrm{w}$ as $\mathrm{t}$ aken $\mathrm{t}$ o $t$ he ne $\mathrm{xt} \mathrm{s}$ tep $\mathrm{w}$ ithout further $\mathrm{p}$ urification, $\mathrm{w}$ here it $\mathrm{w}$ as $\mathrm{c}$ yclized $\mathrm{w}$ ith hydrazine $\mathrm{m}$ onohydrate $\mathrm{i} \mathrm{n}$ a bsolute $\mathrm{e}$ thanol i nto $\mathrm{t}$ he pyrazole $d$ erivative 8. $T$ he $r$ eaction of $t$ he $r$ esulted pyrazole 8 with io doacetonitrile in the $\mathrm{p}$ resence of excess pot assium c arbonate pr oduced $t$ wo di fferent regioisomers. $\mathrm{T}$ he i ntended i somer $\mathbf{9}$ was th e $\mathrm{m}$ ajor product of the reaction with $R_{f}$ value of 0.54 ( EtOAc) while the other isomer was produced as a minor product with hi gher $\mathrm{R}_{\mathrm{f}}$ value of 0.66 ( EtOAc). $\mathrm{T}$ he $\mathrm{r}$ equired isomer 9 was s eparated i $\mathrm{n}$ a $\mathrm{p}$ ure $\mathrm{f}$ orm $\mathrm{b}$ y co lumn chromatography and its structure was confirmed by 2DNOESY NM R s pectrum of the s ubsequent $\mathrm{c}$ ompound 10. Compound 10 was prepared in a moderate y ield (67\%) by S uzuki c oupling of c ompound 9 with 3 pyridineboronic a cid, $\mathrm{i} \mathrm{n}$ the pr esence of di chloro bis(triphenylphosphine)Pd(II) and sodium carbonate, in a mixed solvent of acetonitrile and water in a (1:1) ratio. The 2D -NOESY NM R spectrum of this c ompound confirmed the former nucleophilic substitution with $(S)$ (+)-1-aminopropan-2-ol in compound 7 at the 6-position of the py rimidine $r$ ing ( not $t$ he 2 -position). $T$ his $w$ as proved by the absence of a cross peak between $\mathrm{H}_{5}$ of the pyrimidine $\mathrm{r}$ ing a nd $\mathrm{H}_{2}$ or $\mathrm{H}_{4}$ of $\mathrm{t}$ he py ridyl gr oup (Figure 2a).
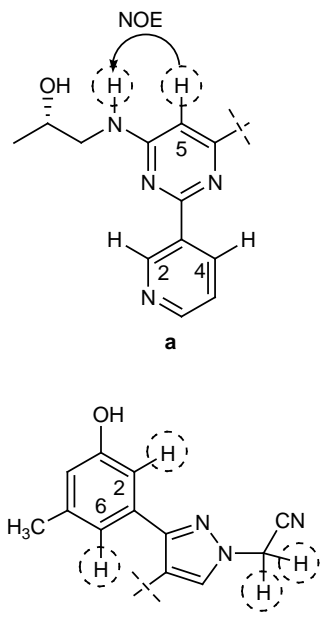

c
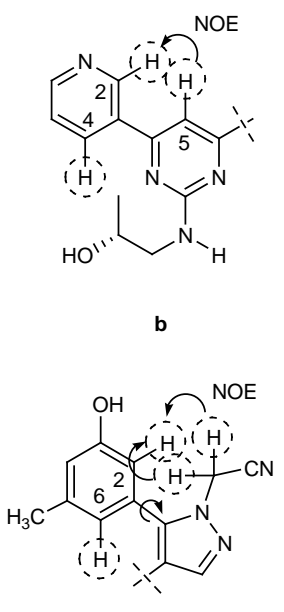

a: NOE effect between aminopropan-2-ol NH and Pyrimidine $\mathrm{H}_{5}$ in compound 10; b: Proposed NOE effect between pyrimidine $\mathrm{H}_{5}$ and $\mathrm{H}_{2}$ or $\mathrm{H}_{4}$ of pyridine in compound $\mathbf{1 0}$ regioisomer; $\mathbf{c}$ : The distance between acetonitrile $-\mathrm{CH}_{2}$ - and the aromatic protons doesn't allow for NOE interaction in compound 10; $\mathbf{d}$ : Proposed NOE effect between acetonitrile $-\mathrm{CH}_{2}$ - and the aromatic protons in the $2 \mathrm{H}$-pyrazole isomer of compound $\mathbf{1 0}$.

Figure 2. NOE interactions in compound 10 and its proposed isomers. 


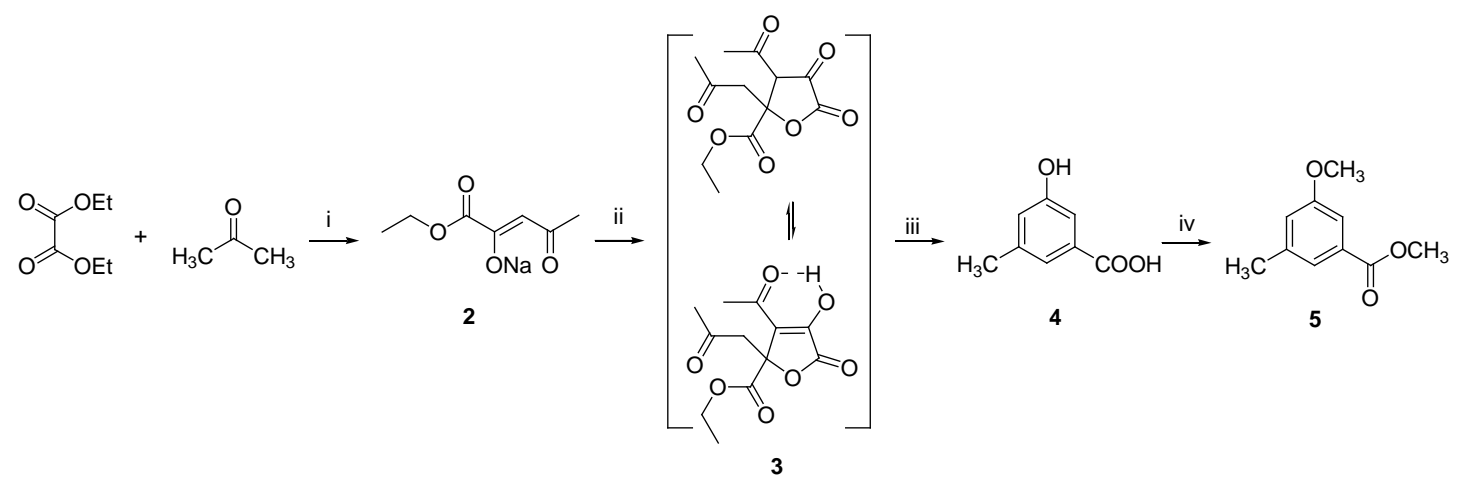

Scheme 1. Reaction conditions and reagents: (i) $\mathrm{NaOEt}$, abs. EtOH, rt, 4 h, 87\%; (ii) acetic acid : $\mathrm{H}_{2} \mathrm{O}(1: 1)$, rt, $2 \mathrm{~h}$, $50 \%$; (iii) $\mathrm{MgO}, \mathrm{H}_{2} \mathrm{O}$, reflux, $45 \mathrm{~min}, 42 \%$; (iv) $\mathrm{K}_{2} \mathrm{CO}_{3}, \mathrm{CH}_{3} \mathrm{I}$, DMAP, acetone, $65{ }^{\circ} \mathrm{C}, 12 \mathrm{~h}, 94 \%$.
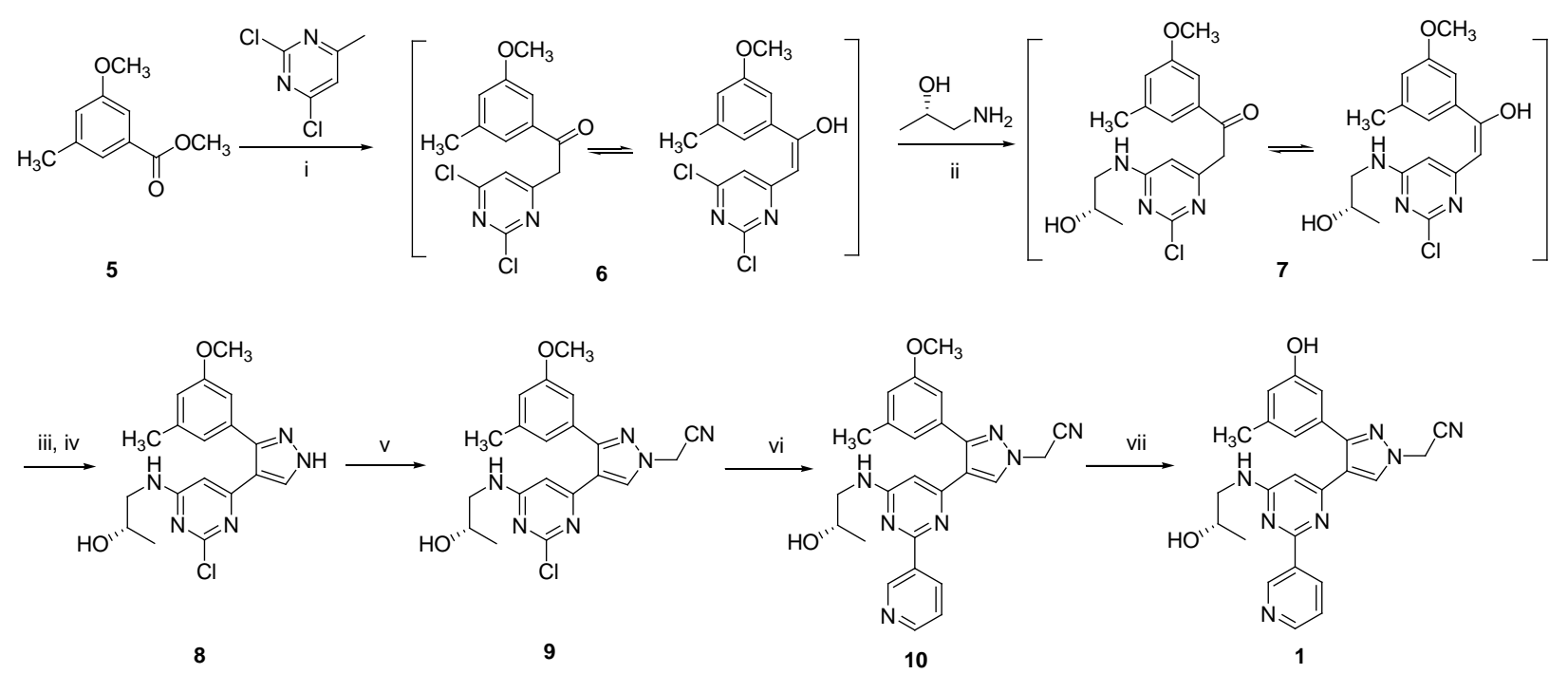

Scheme 2. Reaction conditions and reagents: (i) LHMDS, THF, $\mathrm{N}_{2}$, rt, $24 \mathrm{~h}, 50 \%$; (ii) THF, $80{ }^{\circ} \mathrm{C}, 3 \mathrm{~h}, 35 \%$; (iii) DMF-DMA, $90{ }^{\circ} \mathrm{C}, 20 \mathrm{~h}$; (iv) hydrazine hydrate, a bs. EtOH, rt, $12 \mathrm{~h}, 44 \%$; (v) $\mathrm{K}_{2} \mathrm{CO}_{3}$, io doacetonitrile, acet one, reflux, 2 h, 43\%; (vi) 3-pyridineboronic acid, $\mathrm{Pd}\left(\mathrm{PPh}_{3}\right)_{2} \mathrm{Cl}_{2}, \mathrm{Na}_{2} \mathrm{CO}_{3}, \mathrm{~N}_{2}, \mathrm{CH}_{3} \mathrm{CN} / \mathrm{H}_{2} \mathrm{O}(1: 1), 78{ }^{\circ} \mathrm{C}, 3 \mathrm{~h}, 67 \%$; (vii) $\mathrm{BF}_{3} \cdot \mathrm{S}\left(\mathrm{CH}_{3}\right)_{2}$, dichloromethane, $\mathrm{N}_{2}, \mathrm{rt}, 12 \mathrm{~h}, 45 \%$.

The presence of such cross peak would be expected if the $\mathrm{s}$ ubstitution $\mathrm{w}$ ith $(S)-(+)-1$-aminopropan-2-ol occurred at the $\mathrm{C}_{2}$ of the pyrimidine, since in this case, the subsequent substitution with pyridin-3-yl m oiety would happen at the 6 position of pyrimidine, allowing through space interaction between $\mathrm{H}_{5}$ of the pyrimidine and $\mathrm{H}_{2}$ or $\mathrm{H}_{4}$ of the pyridine (Figure $2 \mathrm{~b}$ ). Furthermore, the presence of a cross peak between pyrimidine $\mathrm{H}_{5}$ and the $\mathrm{NH}$ of the aminopropan-2-ol provides another evidence $f$ or $t$ he pr esence of $t$ he a minopropan-2-ol group at the 6 pos ition of the py rimidine $r$ ing (Figure 2a). It was important also to prove that the former isomer 9 is $\mathrm{t}$ he i ntended $1 \mathrm{H}$-pyrazole not $\mathrm{t}$ he $2 \mathrm{H}-$ pyrazole. This was proved too by the 2D-NOESY NMR spectrum of compound 10, by the absence of any cross peak $\mathrm{t}$ hat $\mathrm{m}$ ight $\mathrm{i}$ ndicate a $\mathrm{t}$ hrough $\mathrm{s}$ pace $\mathrm{i}$ nteraction between the $-\mathrm{CH}_{2}$ - protons of the acetonitrile group and any of $t$ he a romatic pr otons of $t$ he 3 -methoxy-5methylphenyl group (Figure 2c). The presence of such cross-peaks would be expected if this isomer is the $2 \mathrm{H}$ pyrazole, $\mathrm{s}$ ince the a cetonitrile gr oup $\mathrm{w}$ ould be c lose enough $t$ ot he a romatic pr otons of 3 -methoxy-5methylphenyl group to exhibit NOE effect as shown in Figure $2 \mathrm{~d}$. The final hy droxyl product 1 was o btained by d emethylation of the m ethoxy gr oup of c ompound 10 using 10 equivalents of bor ontrifluoridedimethylsulfide complex in dichloromethane. 
The sc reening results of the target compound 1 over 45 di fferent ki nases $h$ ave $r$ evealed $t$ hat the inhibitory activity of the compound was not exhibited over almost all of the tested kinases, while high potency and activity was selectively shown at Ros1 kinase only (Table 1).

Table 1. Percantages of enzymatic activities and inhibitions exerted by compound $\mathbf{1}^{25}$ on 45 kinases $^{26}$

\begin{tabular}{|c|c|c|}
\hline Kinase Enzyme & $\%$ Activity $^{\mathrm{a}, \mathrm{b}, \mathrm{c}}$ & $\%$ Inhibition $^{\mathrm{d}}$ \\
\hline ABL1 & 79.56 & 20.44 \\
\hline AKT1 (dPH, S473D) & 102.97 & -2.97 \\
\hline Aurora A & 78.25 & 21.75 \\
\hline BRAF & 91.03 & 8.97 \\
\hline CDK1/cyclinB & 96.36 & 3.64 \\
\hline CHK1 & 97.64 & 2.36 \\
\hline CK1 epsilon & 90.68 & 9.32 \\
\hline c-Kit & 97.15 & 2.85 \\
\hline c-MET & 94.18 & 5.82 \\
\hline c-Src & 83.82 & 16.18 \\
\hline DAPK1 & 101.17 & -1.17 \\
\hline DNA-PK & 93.44 & 6.56 \\
\hline EGFR & 102.23 & -2.23 \\
\hline EPHA1 & 76.73 & 23.27 \\
\hline FAK/PTK2 & 96.57 & 3.43 \\
\hline FGFR1 & 108.05 & -8.05 \\
\hline FGR & 96.66 & 3.34 \\
\hline FLT1 & 101.67 & -1.67 \\
\hline FYN & 107.86 & -7.86 \\
\hline HIPK1 & 103.43 & -3.43 \\
\hline IKKa/CHUK & 98.63 & 1.37 \\
\hline IR & 92.99 & 7.01 \\
\hline JAK1 & 90.85 & 9.15 \\
\hline JNK1a1 & 96.17 & 3.83 \\
\hline KDR/VEGFR2 & 105.84 & -5.84 \\
\hline LCK & 89.72 & 10.28 \\
\hline LYN & 101.45 & -1.45 \\
\hline MEK1 & 106.97 & -6.97 \\
\hline MST4 & 101.54 & -1.54 \\
\hline MUSK & 100.42 & -0.42 \\
\hline P38a/MAPK14 & 94.73 & 5.27 \\
\hline p70S6K & 94.21 & 5.79 \\
\hline PAK4 & 98.63 & 1.37 \\
\hline PIM1 & 94.09 & 5.91 \\
\hline $\mathrm{PKCa}$ & 90.77 & 9.23 \\
\hline PLK1 & 94.15 & 5.85 \\
\hline RAF1 & 79.61 & 20.39 \\
\hline RET & 93.35 & 6.65 \\
\hline ROCK1 & 88.28 & 11.72 \\
\hline RON/MST1R & 71.08 & 28.82 \\
\hline ROS/ROS1 & 6.08 & 93.92 \\
\hline SYK & 91.77 & 8.23 \\
\hline TIE2/TEK & 91.83 & 8.17 \\
\hline TRKA/NTRK1 & 100.14 & -0.14 \\
\hline YES & 102.59 & -2.59 \\
\hline
\end{tabular}

The c ompound $w$ as t ested initially at a s ingle d ose concentration of $10 \mu \mathrm{M}$. At this concentration, a $93.92 \%$ inhibition of the enzymatic activity of Ros1 kinase was observed, $w$ hile $t$ he i nhibition i n a ctivity $\mathrm{w}$ as be low $30 \%$ in all of the other kinases, and in the range of 20$30 \%$ i n 5 ki nases only (ABL1, Aurora A , E PHA1, RAF1 \& RON/MST1R).

Compound 1 was further tested over R os 1 kinase in order to determine its $\mathrm{IC}_{50}$, where a 10 -dose $\mathrm{IC}_{50}$ mode with $3 \mathrm{f}$ old $\mathrm{s}$ eriald ilutions s tarting a t $20 \mu \mathrm{M}$ concentration $w$ as a pplied a gainst $\mathrm{S}$ taurosporine $\mathrm{e}^{22-24}$ as a $r$ eference $s$ tandard ( Figure 3 ). The $\mathrm{c}$ ompound $\mathrm{h}$ as showed an $\mathrm{IC}_{50}$ value of $199 \mathrm{nM}$, while the $\mathrm{IC}_{50}$ value for the non-selective kinase inhibitor Staurosporine was $0.07 \mathrm{nM}$.
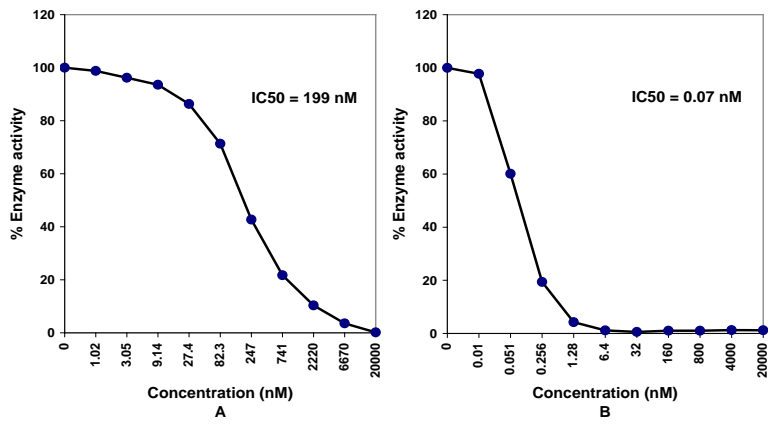

(A) Dose-activity curve for compound 1 on Ros 1 kinase

(B) Dose-activity curve for Staurosporine on Ros1 kinase

Figure 3. Dose-activity curves

The high s electivity of compound $\mathbf{1}$ to R os1 kinase and the diminished activity over the other kinases could be a ttributed to the increased bul kiness exerted by the sbstituents a $t$ pyrimidine nucleus. $T$ his $\mathrm{i}$ ncrease $\mathrm{i} \mathrm{n}$ bulkiness seems to hinder the fitting of the compound to the binding sites of most of these kinases and to exclude it $f$ rom $t$ heir bi nding poc kets. $\mathrm{H}$ owever, $t$ he s elective inhibition of $\mathrm{R}$ os 1 ki nase $m$ ight be ow ed to a uni que difference in the geometry of the binding pocket of this enzyme that e nables t he fitting a nd $i$ nteraction of compound 1. An indirect inhibitory effect of compound 1 at Ros1 ki nase, pr obably t hrough bi nding a $t$ a $n$ allosteric bi nding s ite, is a nother pos sible a ssumption for $t$ he $r$ eason behind $t$ his s elective $i$ nhibition. $T$ he absolute $r$ eason is s till $u$ nclear an $\mathrm{d} w \mathrm{e} b$ elieve that it worth $f$ urther e xploration $f$ or $t$ he $m$ echanism of $i$ ts unique inhibitory effect.

In conclusion, a highly potent and selective in hibitor for Ros1 kinase has been synthesized and can be used as a promising lead for new selective inhibitors for R os 1 kinase. It worth also to mention that until now, no selective inhibitor is available for Ros1 kinase, and the development of new selective inhibitors for such kinase might o pen the way for $n$ ew s elective therapeutics for astrocytomas. S creening of $\mathrm{c}$ ompound 1 against glioblastoma derived tumors is currently undergoing. 


\section{Acknowledgment}

This $r$ esearch $w$ as s upported by Korea I nstitute of Science an d T echnology and B io-strategy T echnology Research Program through Korea Institute of Industrial Technology E valuation and Planning funded by Ministry of Knowledge Economy. We also appreciate to Dr. Sean W. Deacon and D r. Haiching M a from Reaction Biology Corporation for kinase screening.

\section{References and Notes}

1. Alaoui-Jamali, M. A. Biomed. Pharmacother. 2006, 60,629 .

2. Chase, A.; Cross, N. C. P. Clin. Sci. 2006, 111, 233.

3. Perona, R. Clin. Transl. Oncol. 2006, 8, 77.

4. Hubbard, S. R.; Miller, W. T. Curr. Opin. Cell Biol. 2007, 19, 117.

5. Gupta, R.; Knight. C. L.; Bain, B. J. Br. J. Haematol. 2002, 117, 489.

6. Chalandon, Y .; S chwaller, J . Haematologica 2005, 90, 949 .

7. Lengyel, E.; Sawada, K.; Salgia, R. Curr. Mol. Med. 2007, 7, 77.

8. Sequist, L. V.; L ynch, T. J. Annu. Rev. Med. 2008, $59,429$.

9. Nagarajan, L.; Louie, E.; T sujimoto, Y.; Balduzzi, P. C.; Huebner, K.; Croce, C. M. Proc. Natl. Acad. Sci. U. S. A. 1986, 83, 6568.

10. Matsushime, H.; Wang, L. H.; Shibuya, M. Mol. Cell Biol. 1986, 6, 3000.

11. Birchmeier, C.; S harma, S.; W igler, M. Proc. Natl. Acad. Sci. U. S. A. 1987, 84, 9270.

12. Charest, A.; K heifets, V.; P ark, J.; L ane, K.; McMahon, K.; Nutt, C. L.; Housman, D. Proc. Natl. Acad. Sci. U. S. A. 2003, 100, 916.

13. Charest, A.; L ane, K.; Mc Mahon, K.; P ark, J.; Preisinger, E.; C onroy, H.; Ho usman, D. Gene. Chromosome. Canc. 2003, 37, 58-71.

14. Jun, H. J .; W oolfenden, S.; C oven, S.; L ane, K.; Bronson, R.; Housman, D.; Charest, A. Cancer Res. 2009, 69, 2180.

15. Holland, E. C. Proc. Natl. Acad. Sci. U. S. A. 2000 , 97,6242 .

16. Hess, S. M.; Anderson, J. G .; B ierbach, U. Bioorg. Med. Chem. Lett. 2005, 15, 443.

17. Van de Kelft, E. Acta Neurochir. 1997, 139, 589.

18. Ohgaki, H.; K leihues, P. Am. J. Pathol. 2007, 170, 1445 .

19. Wipf, P.; M ahler, S. G. ; Ok umura, K. Org. Lett. 2005, 7, 4483.

20. Turner, F. A.; Gearien, J. E. J. Org. Chem. 1959, 24, 1952.

21. De Frutos, O.; Atienza, C.; Echavarren, A. M. Eur. J. Org. Chem. 2001, 1, 163.

22. Omura, S.; Sa saki, Y.; I wai, Y.; T akeshima, H. J. Antibiot. (Tokyo), 1995, 48, 535.
23. Gescher, A. Crit. Rev. Oncol. Hematol. 2000, 34, 127.

24. Yang, S.; Malaviya, R.; Wilson, L. J.; Argentieri, R.; Chen, X.; Y ang, C.; W ang, B.; Cavender, D.; Murray, W. V. Bioorg. Med. Chem. Lett. 2007, 17, 326.

25. Preparation of $\mathrm{c}$ ompound 1: To a $\mathrm{s}$ olution o $\mathrm{f}$ compound $10(75 \mathrm{mg}, 0.16 \mathrm{mmol})$ in dichloromethane $(3$ $\mathrm{mL}$ ) was a dded bor ontrifluoride-methyl s ulfide $\mathrm{c}$ omplex $(172 \mu \mathrm{L}, 1.65 \mathrm{mmol})$ in a dropwise manner at room temperature a nd $\mathrm{u}$ nder $\mathrm{N}_{2}$ atmosphere. $\mathrm{T}$ he $\mathrm{r}$ esulting suspension was stirred for $12 \mathrm{~h}$ ours, and then the mixture was co ncentrated $\mathrm{u}$ nder $\mathrm{v}$ acuum. $\mathrm{T}$ he $\mathrm{r}$ esidue was partitioned be tween e thylacetate $(100 \mathrm{~mL})$ a nd br ine ( 50 $\mathrm{mL}$ ). $\mathrm{T}$ he o rganic 1 ayer was s eparated an $\mathrm{d} d$ ried over anhydrous $\mathrm{M} \mathrm{gSO}_{4}$, $\mathrm{t}$ hen e vaporated und er va cuum. $\mathrm{T}$ he residue $\mathrm{w}$ as $\mathrm{p}$ urified $\mathrm{b}$ y co lumn $\mathrm{c}$ hromatography ( silica gel, methanol-dichloromethane 1:30, v/v) to yield the pure hydroxyl product 1 as a white powder ( $32.5 \mathrm{mg}, 45 \%)$; mp 236-237 ${ }^{\circ} \mathrm{C} ;{ }^{1} \mathrm{H}-\mathrm{NMR}\left(\mathrm{CD}_{3} \mathrm{OD}\right) \delta 1.09(\mathrm{~d}, J=5.7 \mathrm{~Hz}, 3 \mathrm{H})$, $2.21(\mathrm{~s}, 3 \mathrm{H}), 3.25(\mathrm{~s}, 1 \mathrm{H}), 3.38(\mathrm{bs}, 1 \mathrm{H}), 3.87(\mathrm{bs}, 1 \mathrm{H})$, $5.32(\mathrm{~s}, 2 \mathrm{H}), 6.65(\mathrm{~s}, 1 \mathrm{H}), 6.69(\mathrm{~s}, 1 \mathrm{H}), 6.76(\mathrm{~s}, 1 \mathrm{H}), 6.86$ (s, $1 \mathrm{H}), 7.38-7.41(\mathrm{~m}, 1 \mathrm{H}), 8.14(\mathrm{~d}, J=8.1 \mathrm{~Hz}, 1 \mathrm{H}), 8.28$ (s, 1H), $8.49(\mathrm{~d}, J=3.5 \mathrm{~Hz}, 1 \mathrm{H}), 8.81(\mathrm{~s}, 1 \mathrm{H})$; IR (KBr) $3425,2926,2360,1586,1454,1349,1162 \mathrm{~cm}^{-1}$.

26. Kinase a ssays were $\mathrm{p}$ erformed at $\mathrm{R}$ eaction $\mathrm{B}$ iology Corporation u sing the "HotSpot" a ssay pl atform. Kinase Assay Protocol. Reaction Buffer: base Reaction buffer; 20 $\mathrm{mM}$ Hepes ( $\mathrm{pH} 7.5$ ), $10 \mathrm{mM} \mathrm{MgCl} 2,1 \mathrm{mM}$ EGTA, $0.02 \%$ Brij35, $0.02 \mathrm{mg} / \mathrm{ml} \mathrm{B} \mathrm{SA}, 0.1 \mathrm{mM} \mathrm{Na} \mathrm{VO}_{4}, 2 \mathrm{mM} \mathrm{D} \mathrm{TT}$, $1 \%$ DMSO. Required cofactors were added individually (if needed) to each kinase reaction. Reaction Procedure: To a freshly pr epared bu ffer solution was a dded a ny $r$ equired cofactor $\mathrm{f}$ or $\mathrm{t}$ he en zymatic $\mathrm{r}$ eaction, $\mathrm{f}$ ollowed $\mathrm{b}$ y $\mathrm{t}$ he addition of the selected kinase at a concentration of $20 \mu \mathrm{M}$. The contents were mixed gently, then the compound under test ( compound 1) di ssolved in D MSO was a dded to the reaction mixture i $\mathrm{t}$ he ap propriate co ncentration. 339 ATP ( specific a ctivity $500 \mu \mathrm{Ci} / \mu \mathrm{l}$ ) was added to the mixture in order to initiate the reaction, an $\mathrm{d}$ the mixture was i ncubated a $\mathrm{t} r$ oom $t$ emperature $\mathrm{f}$ or $2 \mathrm{~h}$ ours. Initial screening o ver $45 \mathrm{ki}$ nases: Compound 1 was t ested b y single dose duplicate made at a concentration of $10 \mu \mathrm{M}$. Staurosporine was used as a control compound in a 5-dose $\mathrm{IC}_{50}$ mode with 10 fold serial dilutions starting at $20 \mu \mathrm{M}$. Reaction was car ried o ut a t $10 \mu \mathrm{M}$ A TP co ncentration. Testing against Ros 1 kinase: Compound $\mathbf{1}$ was tested in a 10-dose $\mathrm{IC}_{50}$ mode with 3 fold serial dilutions starting at $20 \mu \mathrm{M}$. Staurosporine was used as a control compound in a 10-dose $\mathrm{IC}_{50}$ mode with 5 fold serial dilutions starting at $20 \mu \mathrm{M}$. R eaction was car ried o ut at $10 \mu \mathrm{M}$ ATP concentration. 